\title{
Sino-European Trade Competition in Latin America and the Caribbean
}

\author{
Wioletta Nowak \\ University of Wroclaw, Wroclaw, Poland
}

\begin{abstract}
The article studies trade in goods between China and the Latin American and Caribbean (LAC) countries and between the European Union (EU) and LAC during the years from 2000 to 2013. From the beginning of the 21st century, big changes in LAC's trade patterns have been observed. The article contains possible explanation of them. The analysis is based on the ECLAC (Economic Commission for Latin America and the Caribbean) data. Merchandise trade between China and LAC grew significantly over the period from 2000 to 2013. In 2013, the value of merchandise exports from China was higher than from the EU-28 in the case of 12 LAC countries. Chinese imports of goods surpassed the European ones in five countries in the region. In order to increase its exports of manufactured goods and imports of natural resources and agricultural commodities, China combines trade arrangements with foreign aid policy. Besides, a rapid development of bilateral diplomatic ties between China and LAC is observed. The EU-LAC trade relations have worsened during the last decade mainly due to financial crisis and development of the EU-Asia trade relations.
\end{abstract}

Keywords: China, merchandise trade, foreign aid, European Union (EU)

\section{Introduction}

The European Union (EU) and China (after the United Sates) are the most important trading partners for the Latin American and Caribbean (LAC). Since the beginning of the 21st century, a rapid expansion of Sino-Latin trade and economic relations has been observed. China is likely to surpass the EU and be LAC's second largest trade partner in a few years. China's ties with Latin America are not new. However, their dynamics in recent years were really spectacular. The significant increase in trade between China and LAC countries was observed after the beginning of the financial crisis. Besides, from 2008, China has become a major source of financing for many countries in the region. China uses its loans to develop bilateral trade relations with the LAC states.

After the financial crisis, the EU was mainly concentrated on the struggle against its effects. In order to restore its economy, the EU developed closer economic and trade relations with Asia. At the same time, the EU-LAC trade relations have worsened. Although, the EU increased its aid-for-trade with LAC countries, it has been gradually losing its importance for LAC as a destination for exports and as a source for imports.

In the literature, trade relations between China and Latin America and between the EU and LAC are mainly examined separately (Bárcena \& Rosales, 2010; Bárcena, Prado, Rosales, \& Pérez, 2012; Roy, 2012).

Wioletta Nowak, Ph.D., University of Wroclaw, Wroclaw, Poland.

Correspondence concerning this article should be addressed to Wioletta Nowak, Institute of Economic Sciences, Uniwersytecka 22/26, 50-145 Wroclaw, Poland. E-mail: wnowak@prawo.uni.wroc.pl. 
The aim of the paper is to study China-LAC and the EU-LAC trade relations in the first decade of the 21 st century using the same data set. The analysis is principally based on the EULAC data.

\section{Development of China-LAC and the EU-LAC Trade Relations}

Trade between China and Latin America is dated back to the 1560s. At that time, Chinese ships sailed to Acapulco in Mexico via Manila. China exported mainly silk, cotton cloths, jewellery, and gun powder to Latin America, and imported wine, olive, oil, soap, and food. In 1815, this "silk-road" on the sea between China and Latin America was closed due to an implementation of the Chinese export control policy (Jiang, 2006, p. 69).

In the 19th century, Sino-Latin American relations took a different form. The basis of ties was the Chinese immigration. Hundreds of thousands of Chinese workers migrated to the Latin American countries (Mexico, Brazil, Chile, Panama, and Peru) where they mainly worked in mines and on plantations (Ratliff, 2009, p. 2).

After the proclamation of People's Republic of China in 1949, economic cooperation between China and LAC was still limited. Trade exchange was insignificant, not to mention investments. The situation was a consequence of a lack of diplomatic contacts at high governmental levels between China and LAC states and the poor condition of the Chinese economy.

In the 1950s, Sino-Latin American ties were restricted to visits of individual Latin Americans. LAC countries began to establish diplomatic relations with China just in the 1970s. The first countries that recognized People's Republic of China in the region were Cuba and Chile. Cuba established diplomatic relations with China in $1960^{1}$ and Chile 10 years later. Then, other major countries in the region began to recognize China. ${ }^{2}$ It happened mainly because of two significant events: In 1971, the government of People's Republic of China was recognised as the legal representative of China in the United Nations (UN) and was given the permanent seat in the UN Security Council; in February 1972, President Richard Nixon visited China, after which the pressure from the United States declined and Latin countries which were always in the orbit of the American influence could begin to establish diplomatic relations with China.

China-LAC trade relations accelerated after Deng Xiaoping's reforms in 1978. China's rapid economic growth and its constantly increasing demand for natural resources, food and new markets caused that it had to find new trade partners. China, among others, turned to resource-rich Latin America.

Until now, China has got preferential access to three markets in the region (Table 1). It signed free trade agreement (FTA) with Chile, Peru, and Costa Rica. FTAs cover items on the World Trade Organization's new trade agenda. It means that they concern not only the deregulation and liberalization of goods markets but also services and investment. Besides, in 2012, China declared readiness to negotiate with Mercosur (Argentina, Brazil, Paraguay, Uruguay, and Venezuela) on a free trade area.

Sino-Latin American trade relations are developed and strengthened also during high-level visits. A significant increase in official visits to LAC by the highest Chinese authorities has been recorded since 2001 . Diplomatic relations were developed and maintained by Jiang Zemin and his successors $\mathrm{Hu}$ Jintao and Xi Jinping (Table 2).

\footnotetext{
${ }^{1}$ After the Sino-Soviet split in the 1960s, Cuba chose the Soviet Union and froze its relation with China. Both countries normalised relations after the collapse of the Soviet Union.

${ }^{2}$ In 2014, People's Republic of China was recognized by 21 LAC countries: Cuba (1960), Chile (1970), Peru (1971), Mexico (1972), Argentina (1972), Guyana (1972), Jamaica (1972), Trinidad and Tobago (1974), Venezuela (1974), Brazil (1974), Suriname (1976), Barbados (1977), Ecuador (1980), Colombia (1980), Antigua and Barbuda (1983), Bolivia (1985), Grenada (1985), Uruguay (1988), Bahamas (1997), Dominica (2004), and Costa Rica (2007).
} 
Table 1

Trade Agreements Between China and the Latin American Countries

\begin{tabular}{llll}
\hline Agreement name & Type & Coverage & Date of entry into force \\
\hline Chile to China & FTA \& EIA & Goods \& Services & 01-Oct-2006 (Goods), 01-Aug-2010 (Services) \\
China to Costa Rica & FTA \& EIA & Goods \& Services & 01-Aug-2011 \\
Peru to China & FTA \& EIA & Goods \& Services & 01-Mar-2010 \\
\hline
\end{tabular}

Note. EIA: Economic Integration Agreement. Source: Retrieved from http://rtais.wto.org/UI/PublicAllRTAList.aspx.

Table 2

Development of Bilateral Ties Between China and Latin America and the Caribbean in the Years 2001-2014

\begin{tabular}{lll}
\hline Year & Chinese authority & Visited LAC countries \\
\hline 2001, April & President Jiang Zemin & Chile, Argentina, Uruguay, Brazil, Cuba, Venezuela \\
2003, December & Prime Minister Wen Jiabao & Mexico \\
2004, November & President Hu Jintao & Chile, Brazil, Argentina, Cuba \\
2005, September & President Hu Jintao & Mexico \\
2008, November & President Hu Jintao & Peru, Costa Rica, Cuba \\
2009, February & Vice President Xi Jinping & Mexico, Jamaica, Colombia, Venezuela, Brazil \\
2010, April & President Hu Jintao & Brazil \\
2011, June & Vice President Xi Jinping & Cuba, Uruguay, Chile \\
2012, June & Prime Minister Wen Jiabao & Brazil, Uruguay, Argentina, Chile \\
2013, May/June & President Xi Jinping & Trinidad and Tobago, Costa Rica, Mexico, \\
2014, July & President Xi Jinping & Brazil, Argentina, Venezuela, Cuba \\
\hline
\end{tabular}

Moreover, the China Council for the promotion of international trade has initiated so far eight China-Latin America business summits which are also an important platform for trade cooperation between China and LAC. The first was held in Santiago, Chile (2007), the second in Harbin, China (2008), and the next in Bogota, Colombia (2009), Chengdu, China (2010), Lima, Peru (2011), Hangzhou, China (2012), San Jose, Costa Rica (2013), and Changsha, China (2014).

Europe and LAC are linked through historical, cultural, political, and economic ties which are dated back to 1492. However, contemporary relations between the EU and LAC were regulated in 1999 during the first EU-LAC summit which was held in Rio de Janeiro, Brazil. The main achievement of the summit was the establishment of a strategic partnership between the EU and LAC. Since then, issues referring to a mutual cooperation in the area of free trade between the regions are discussed during biannual EU-LAC summits. So far six bi-regional summits have been held in Madrid, Spain (2002), Guadalajara, Mexico (2004), Vienna, Austria (2006), Lima, Peru (2008), Madrid, Spain (2010), and Santiago, Chile (2013). The summits bring together heads of state and government from both continents. In the years when the EU-LAC summits do not take place, the EU and the Rio Group ${ }^{3}$ meet at ministerial level. In 2010, EU-LAC foundation was created in order to assist in the implementation of main objectives of the strategic partnership between the regions. The Foundation has 63 members: the 28 members of the EU, the 33 LAC states, and the EU institutions (Retrieved from http://eulacfoundation.org/en/about-us).

The EU has privileged relations in trade with the Caribbean and countries of Central America. Besides, the

\footnotetext{
3 The Rio Group was established by Argentina, Brazil, Colombia, Mexico, Panama, Peru, Uruguay, and Venezuela in 1986. The Group eventually extended to 24 Latin American and Caribbean states.
} 
EU signed special agreements with Mexico, Chile, Colombia, and Peru (Table 3). All trade agreements between the EU and LAC relate to deregulation and liberalization of trade in goods and services.

Table 3

Trade Agreements Between the EU and LAC

\begin{tabular}{llll}
\hline Agreement name & Type & Coverage & Date of entry into force \\
\hline EU to CARIFORUM States EPA & FTA \& EIA & Goods \& Services & 01-Nov-2008 \\
$\begin{array}{l}\text { EU to Central America (Costa Rica, El Salvador, } \\
\text { Guatemala, Honduras, Nicaragua, and Panama) }\end{array}$ & FTA \& EIA & Goods \& Services & 01-Aug-2013 \\
EU to Chile & FTA \& EIA & Goods \& Services & 01-Feb-2003 (Goods) \\
EU to Colombia and Peru & FTA \& EIA & Goods \& Services & 01-Mar-2005 (Services) \\
EU to Mexico & FTA \& EIA & Goods \& Services & 01-Jul-2000 (Goods) \\
& & & $01-O c t-2000$ (Services) \\
\hline
\end{tabular}

Note. CARIFORUM includes 14 CARICOM members and the Dominican Republic. Source: Retrieved from http://rtais.wto.org/UI/PublicAllRTAList.aspx.

In 2000, the EU opened negotiations on free trade area with Mercosur. However, there are some obstacles in negotiations concerning sectors which are sensitive for both sides. The EU protects its own production of food via the common agricultural policy and Mercosur wants the access to the European market in agricultural goods. In turn, Mercosur protects its own production of manufactured goods that are the EU's basic export commodities (Roy, 2012, p. 8).

\section{Main Characteristics of Merchandise Trade Between China and LAC and Between the EU and LAC}

Europe has been the second major trading partner (after the United States) for LAC for many years. However, recently, an impressive increase in trade between China and LAC33 (33 countries) has been observed. In the years 2000-2013, the value of China's exports in goods to LAC33 increased about 19 times and Chinese imports in goods from the region increased over 23 times. At that time, the value of the EU25 (25 countries) exports in goods to LAC33 increased about three times. European merchandise imports increased 2.7 times. Trends in merchandise trade between the EU25 and LAC33 and between China and LAC33 over the period 2000-2014 are presented in Figure 1.

In 2000, the value of European merchandise exports to LAC33 was 7.7 times higher than Chinese, but 14 years later only 1.2 times. At the beginning of the century, the value of European merchandise imports from LAC33 was 9.3 higher than China's imports from the region. In 2013, the EU25 imports value was merely 1.1 higher than the Chinese. The EU has been steadily losing its share in Latin American market to China. If the average growth rate of Chinese trade with LAC will be maintained, China is likely to be the second important trading partner for LAC in a few years.

After the beginning of global economic and financial crisis, both China and the EU decreased their trade with LAC. In 2009 compared to 2008 , the Chinese exports declined by $21 \%$ and imports by $10 \%$. In the case of the EU, the figures were respectively $24 \%$ and $31 \%$.

The change in the Chinese merchandise trade with selected Latin American countries over the period from 2000 to 2013 is significantly higher. For instance, during last 14 years, the Chinese exports to Colombia and Peru increased over 40 times. China's imports from Venezuela and Colombia increased over 100 times. In the 
case of Costa Rica, the increase in the Chinese imports was exceptionally high. In the considered years, the EU increased its trade with the Latin American countries a few times (Table 4).
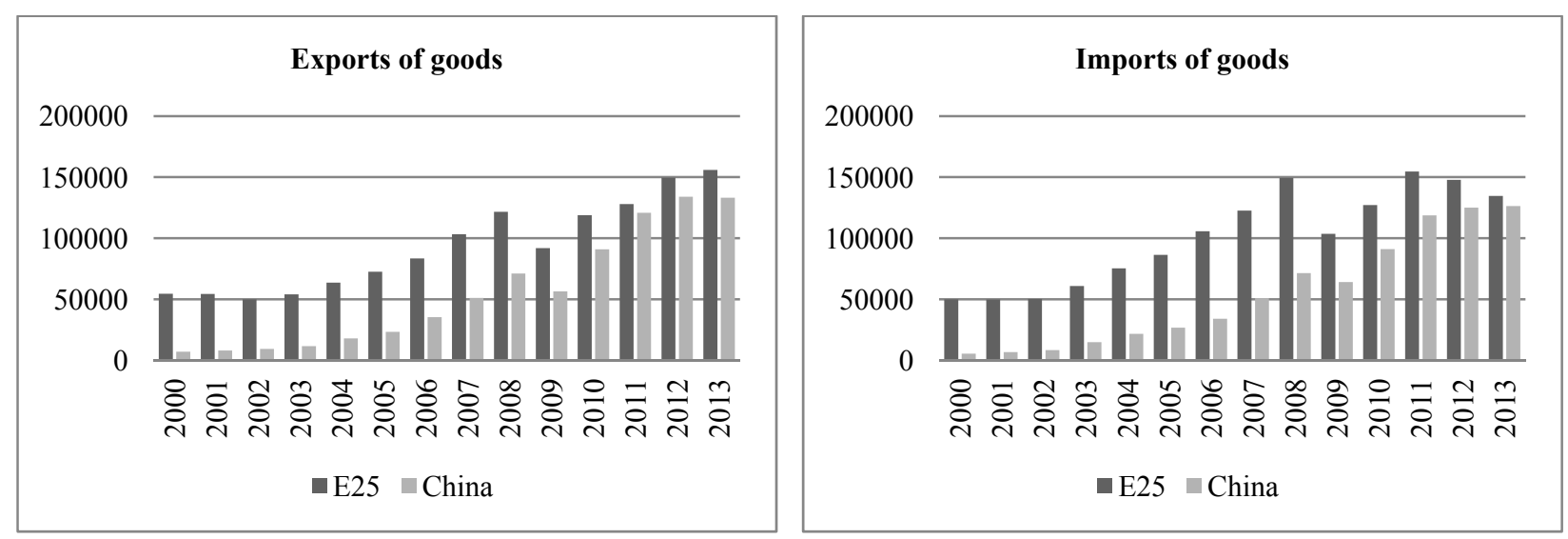

Figure 1. EU25 and China's trade in goods with LAC33 in the years 2000-2013 (USD million). Source: Retrieved from http://www.cepal.org/comercio/ecdata2.

Table 4

Percentage Change in Value of China's and the European Union's Trade in Goods With Selected Latin American Countries in the Years 2000-2013

\begin{tabular}{|c|c|c|c|c|c|c|c|c|c|}
\hline \multirow{2}{*}{ Country } & \multicolumn{2}{|c|}{ China } & \multicolumn{2}{|c|}{ EU25 } & \multirow{2}{*}{ Country } & \multicolumn{2}{|c|}{ China } & \multicolumn{2}{|c|}{ EU25 } \\
\hline & Exports & Imports & Exports & Imports & & Exports & Imports & Exports & Imports \\
\hline Argentina & $1,334 \%$ & $554 \%$ & $132 \%$ & $111 \%$ & Guatemala & $964 \%$ & $3,676 \%$ & $132 \%$ & $82 \%$ \\
\hline Brazil & $2,834 \%$ & $3,249 \%$ & $243 \%$ & $155 \%$ & Mexico & $2,069 \%$ & $1,997 \%$ & $177 \%$ & $242 \%$ \\
\hline Chile & $1,573 \%$ & $1,447 \%$ & $282 \%$ & $149 \%$ & Panama & $752 \%$ & $4,208 \%$ & $153 \%$ & $119 \%$ \\
\hline Colombia & $4,277 \%$ & $11,158 \%$ & $334 \%$ & $356 \%$ & Peru & $4,188 \%$ & $1,401 \%$ & $387 \%$ & $328 \%$ \\
\hline Costa Rica & $1,322 \%$ & $46,041 \%$ & $76 \%$ & $116 \%$ & Uruguay & $856 \%$ & $2,334 \%$ & $182 \%$ & $338 \%$ \\
\hline Cuba & $491 \%$ & $522 \%$ & $83 \%$ & $71 \%$ & Venezuela & $2,264 \%$ & $13,742 \%$ & $96 \%$ & $76 \%$ \\
\hline Ecuador & $3,863 \%$ & $867 \%$ & $509 \%$ & $258 \%$ & & & & & \\
\hline
\end{tabular}

Source: Retrieved from http://www.cepal.org/comercio/ecdata2.

The rise in the Chinese merchandise trade with selected Latin American countries is much more impressive in longer period. During the last 20 years, China has been exponentially increased its trade with countries in the region. China's exports and imports of goods to its most important Latin American trading partners are presented in Figure 2.

A fast growth of the merchandise exchange between China and LAC caused that China has already overtaken the EU in trade with a few countries in the region. In 2013, China exported more commodities than the EU to 12 Latin American countries: Chile, Panama, Venezuela, Peru, Uruguay, Guatemala, Paraguay, Honduras, Jamaica, Nicaragua, Haiti, and Dominica. The Chinese imports value of goods was higher than the European in the case of five countries: Brazil, Chile, Venezuela, Peru, and Uruguay.

Since the beginning of the 21st century, the importance of China as an export market significantly has been increased in a few LAC countries (Table 5). In 2013, China absorbed almost one fourth of the Chilean merchandise exports and one fifth of the Brazilian ones. Besides, over $17 \%$ of the Peruvian and $14 \%$ of the Uruguayan exports were destined in China. A relatively big increase in the share of exports of goods to China in total exports was also observed in the case of Colombia, Argentina, and Panama. China still became an 
unexploited market for Bolivia, Costa Rica, Mexico, or Paraguay. Over the period from 2000 to 2013, China substantially increased its importance as a source of imports for the LAC countries. In 2013, the most dependent countries on Chinese commodities were Paraguay (28.3\% of its imports came from China), Chile (19.7\%), and Peru (19.4\%).
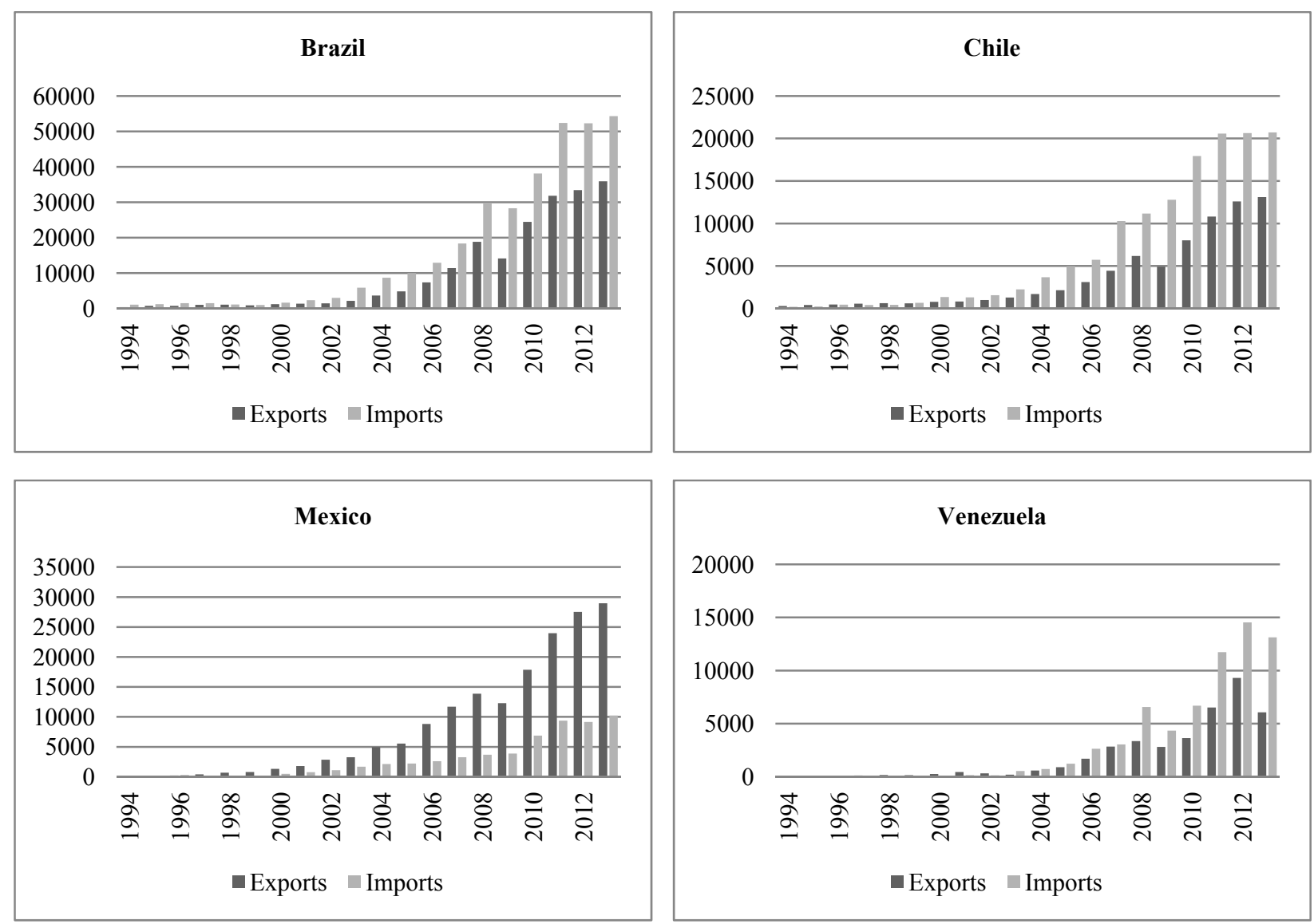

Figure 2. China's exports and imports of goods to Brazil, Chile, Mexico, and Venezuela (USD million) in the years 1994-2013. Source: Retrieved from http://www.cepal.org/comercio/ecdata2.

Table 5

Merchandise Trade of Selected LAC Countries with China in 2000 and 2013 (Percentages of Total Trade)

\begin{tabular}{|c|c|c|c|c|c|c|c|c|c|}
\hline \multirow{2}{*}{ Country } & \multicolumn{2}{|c|}{ Exports } & \multicolumn{2}{|c|}{ Imports } & \multirow{2}{*}{-Country } & \multicolumn{2}{|c|}{ Exports } & \multicolumn{2}{|c|}{ Imports } \\
\hline & 2000 & 2013 & 2000 & 2013 & & 2000 & 2013 & 2000 & 2013 \\
\hline Argentina & 3.0 & 7.2 & 4.6 & 15.4 & Ecuador & 1.2 & 2.3 & 2.2 & 16.7 \\
\hline Bolivia & 0.4 & 2.6 & 3.1 & 12.1 & Mexico & 0.2 & 1.7 & 1.6 & 16.1 \\
\hline Brazil & 2.0 & 19.0 & 2.2 & 15.6 & Panama & 0.2 & 6.1 & 0.6 & 7.9 \\
\hline Chile & 5.0 & 24.8 & 5.7 & 19.7 & Paraguay & 0.7 & 0.6 & 11.5 & 28.3 \\
\hline Colombia & 0.2 & 8.7 & 3.0 & 17.5 & Peru & 6.4 & 17.5 & 3.9 & 19.4 \\
\hline Costa Rica & 0.2 & 3.3 & 1.3 & 9.6 & Uruguay & 4.0 & 14.2 & 3.2 & 16.9 \\
\hline
\end{tabular}

Source: Retrieved from http://www.cepal.org/comercio/ecdata2.

The EU is still an important export market for most of the LAC countries. For instance, in 2009 over 20\% of Brazil's, Honduras' or Panama's exports were destined in EU27. However, in the years from 2000 to 2009, a percentage increase in merchandise exports to EU27 was observed only in Ecuador, Honduras, Panama, 
Paraguay, Venezuela, and four Caribbean countries. In the case of 18 countries in the region, the share of merchandise exports of goods to EU27 in their total exports decreased over the considered period (Bárcena \& Rosales, 2010, p. 13).

An analysis of the structure of China's and Europe's trade with LAC shows some similarities. Namely, both sell to LAC mostly manufactured goods and LAC countries send to them mainly resources and raw materials. China's exports of goods to Latin America consist principally of electronics, components and parts, machinery and equipment, textiles and apparel. In other words, China is a source of imports of cheap manufactured goods for the region (Table 6).

Table 6

Top Five Latin American Trade Partners of China in 2013

\begin{tabular}{|c|c|c|c|c|c|}
\hline \multicolumn{3}{|c|}{ China's exports of goods } & \multicolumn{3}{|c|}{ China's imports of goods } \\
\hline No. & Country & Goods & No. & Country & Goods \\
\hline 1 & Brazil & $\begin{array}{l}\text { Telecommunication equipment, optical } \\
\text { instruments, electrical machinery }\end{array}$ & 1 & Brazil & $\begin{array}{l}\text { Iron ore and concentrates, seeds and } \\
\text { oleaginous fruit, crude petroleum, pulp and } \\
\text { waste paper, sugar and honey }\end{array}$ \\
\hline 2 & Mexico & $\begin{array}{l}\text { Telecommunication equipment, optical } \\
\text { instruments, automatic data processing } \\
\text { machines }\end{array}$ & 2 & Chile & $\begin{array}{l}\text { Copper, ores and concentrates of base } \\
\text { metals, iron ore and concentrates }\end{array}$ \\
\hline 3 & Chile & $\begin{array}{l}\text { Telecommunication equipment, } \\
\text { footwear, cloths }\end{array}$ & 3 & Venezuela & $\begin{array}{l}\text { Crude petroleum and oils, petroleum } \\
\text { products }\end{array}$ \\
\hline 4 & Panama & $\begin{array}{l}\text { Petroleum products, ships, boats and } \\
\text { floating structure }\end{array}$ & 4 & Mexico & $\begin{array}{l}\text { Ores and concentrates of base metals, } \\
\text { passenger motor vehicles, microcircuits, } \\
\text { transistors }\end{array}$ \\
\hline 5 & Argentina & Telecommunication equipment & 5 & Peru & $\begin{array}{l}\text { Ores and concentrates of base metals, iron } \\
\text { ore and concentrates, copper }\end{array}$ \\
\hline
\end{tabular}

Source: Retrieved from http://www.cepal.org/comercio/ecdata2.

Table 7

Top Five Latin American Trade Partners of the European Union in 2013

\begin{tabular}{|c|c|c|c|c|c|}
\hline \multicolumn{3}{|c|}{ EU25 exports of goods } & \multicolumn{3}{|c|}{ EU25 imports of goods } \\
\hline No. & Country & Goods & No. & Country & Goods \\
\hline 1 & Brazil & $\begin{array}{l}\text { Medicinal and pharmaceutical products, } \\
\text { motor vehicle parts and accessories, } \\
\text { petroleum products, aircraft and } \\
\text { associated equipment }\end{array}$ & 1 & Brazil & $\begin{array}{l}\text { Iron ore and concentrates, feeding stuff for } \\
\text { animals, seeds and oleaginous fruit, coffee, } \\
\text { crude petroleum }\end{array}$ \\
\hline 2 & Mexico & $\begin{array}{l}\text { Petroleum products, medicinal and } \\
\text { pharmaceutical products, motor vehicle } \\
\text { parts and accessories }\end{array}$ & 2 & Mexico & $\begin{array}{l}\text { Crude petroleum and oils, } \\
\text { telecommunication equipment, passenger } \\
\text { motor vehicles }\end{array}$ \\
\hline 3 & Argentina & $\begin{array}{l}\text { Petroleum products, motor vehicle parts } \\
\text { and accessories, medicinal and } \\
\text { pharmaceutical products }\end{array}$ & 3 & Chile & $\begin{array}{l}\text { Copper, ores and concentrates of base } \\
\text { metals, fruit and nuts }\end{array}$ \\
\hline 4 & Chile & $\begin{array}{l}\text { Aircraft and associated equipment, } \\
\text { passenger motor vehicles, crude } \\
\text { petroleum }\end{array}$ & 4 & Argentina & $\begin{array}{l}\text { Feeding stuff for animals, chemical products, } \\
\text { ores and concentrates of base metals }\end{array}$ \\
\hline 5 & Colombia & $\begin{array}{l}\text { Medicinal and pharmaceutical products, } \\
\text { aircraft and associated equipment }\end{array}$ & 5 & Colombia & Crude petroleum and oils, coal, fruit and nuts \\
\hline
\end{tabular}

Source: Retrieved from http://www.cepal.org/comercio/ecdata2.

Latin America is important destination for the European medicinal and pharmaceutical products, motor vehicles and aircraft (Table 7). Latin American exports mainly copper, iron and steel, oil, natural gas, coal, 
soya beans, beef, bananas, and coffee to China and the EU. On average, the LAC countries sell more different products to the EU than to China (Bárcena et al., 2012, p. 40). Of the LAC countries, only Mexico exports more technology-intensive products to China and the EU.

\section{Foreign Aid as a Tool of Promoting Trade With LAC Countries}

China uses different methods to increase its trade in goods with other countries. One of the most effective tools is foreign aid. Depending on the region and country, China provides grants, interest-free loans or concessional loans to countries with which it trades. In the case of the LAC countries, low-interest loans dominated in the Chinese foreign aid policy. It is estimated that China offered about USD 100 billion to the region in the years from 2005 to 2013 (Figure 3).

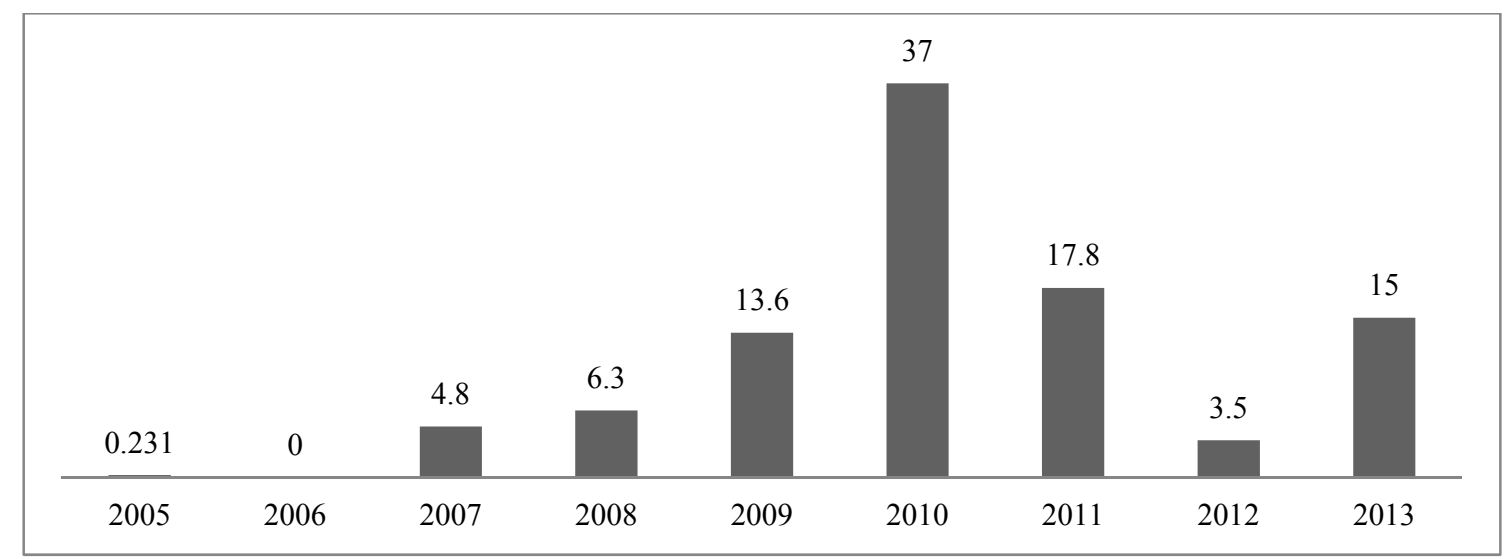

Figure 3. China's lending to Latin America and the Caribbean in the years 2005-2013 (USD billion). Source: Gallagher, Irwin, and Koleski (2012).

Over $90 \%$ of China's lending to LAC was pledged after 2007. In 2010, China's loan commitments to the region were more than combined loans of the Inter-American Development Bank, World Bank, and United States Export-Import Bank to LAC (Gallagher et al., 2012, p. 1).

During the financial crisis, China provided low-interest loans mainly to four resource-rich countries in the region: Venezuela (USD 50.6 billion), Argentina (USD 14.1 billion), Brazil (USD 13.4 billion), and Ecuador (USD 9.9 billion). China was the last resort of financing for countries like Argentina, Ecuador, and Venezuela that were not able to borrow easily in international capital markets. The data about Chinese lending to LAC in the years from 2005 to 2013 are presented in Table 8.

Table 8

China's Lending to Selected Latin American and Caribbean States in the Years 2005-2013 (USD Billion)

\begin{tabular}{lllllc}
\hline Country & Value of loans & Country & Value of loans & Country & Value of loans \\
\hline Argentina & 14.1 & Colombia & 0.075 & Peru & 2.3 \\
Bolivia & 0.611 & Costa Rica & 0.789 & Uruguay & 0.01 \\
Brazil & 13.4 & Ecuador & 9.9 & Venezuela & 50.6 \\
Chile & 0.15 & Mexico & 2.4 & & \\
\hline
\end{tabular}

Source: Gallagher et al. (2012).

Besides, in July 2014, Chinese President Xi Jinping announced additional USD seven billion to Argentina, USD five billion to Brazil, and USD 5.7 billion in loan and USD five billion in credit line to Venezuela (Lee, 
2014). A sharp increase in the Chinese financing provided to LAC in the second half of the first decade of 21 st century coincided with the rise of trade in goods between China and countries in the region.

The EU members and institutions have been provided official development assistance to Latin America and the Caribbean for many years. Since 2001, European grants and concessional loans have been more often directed to trade-related projects and programmes ${ }^{4}$. The EU increased its aid-for-trade disbursements to LAC countries after the Hong Kong WTO Ministerial Conference (Nowak, 2014, p. 77). The European aid-for-trade to the region in the years 2002-2011 is presented in Figure 4.

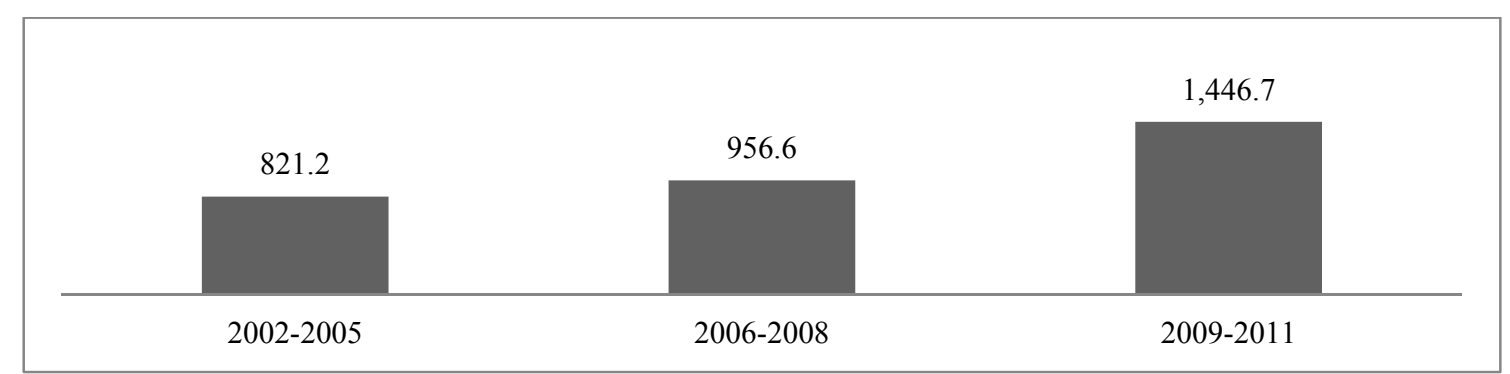

Figure 4. The European Union's aid-for-trade commitments to LAC (USD million, 2011 constant). Source: Retrieved from http://dx.doi.org/10.1787/aid_glance-2013-en.

From the report Aid for Trade at a Glance 2013, it follows that in 2010, the EU provided aid-for-trade to 25 LAC countries. The volumes of aid varied across the states. The EU supported trade-related projects mainly in the poorest countries of the region: The major ones were Peru, Haiti, Honduras, and Jamaica (Figure 5).

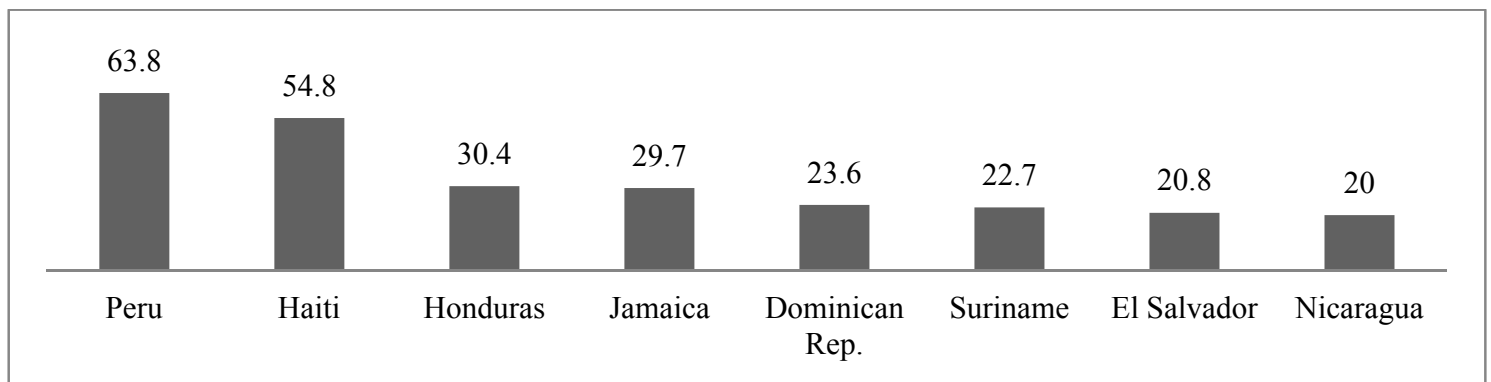

Figure 5. The European Union's aid-for-trade disbursements to selected LAC countries in 2010 (USD million, 2011 constant). Source: Retrieved from http://dx.doi.org/10.1787/aid_glance-2013-en.

The level of the European aid was lower than China's aid. It is worth noting that in the years from 2005 to 2010, from 12 LAC countries to which China exported more commodities than the EU in 2013, only Chile and Venezuela were not supported by the EU under the aid-for-trade program.

\section{Conclusions}

The LAC countries are not the most important trading partners for the EU and China. In 2013, the EU's exports to LAC represented only $6.7 \%$ of total and imports $6.0 \%$. Exports and imports figures for China were similar 6.0\% and 6.5\%, respectively (Retrieved from http://www.cepal.org/comercio/ecdata2). However, the region became the area of Sino-European trade competition especially since the second half of the 21 st century.

\footnotetext{
${ }^{4}$ In 2001, the Development Assistance Committee announced The DAC Guidelines Strengthening Trade Capacity for Development.
} 
A significant growth in trade between China and LAC countries has been observed since the beginning of the global financial crisis. China, providing a huge amount of low-interest loans to LAC countries and developing diplomatic relations with them, has been constantly increasing bilateral trade in goods with the region. At the same time, the EU was also provided grants and concessional loans to support LAC's efforts in expanding its trade. However, the EU more concentrated on development of trade relations with the Asian than LAC countries. As a result, the EU has been losing its priority for LAC.

\section{References}

Bárcena, A., \& Rosales, O. (2010). The People's Republic of China and Latin America and the Caribbean: Towards a strategic relationships (Economic Commission for Latin America and the Caribbean, Chile).

Bárcena, A., Prado, A., Rosales, O., \& Pérez, R. (2012). Latin America and the Caribbean and the European Union: Striving for a renewed partnership (Economic Commission for Latin America and the Caribbean, Chile).

Economic Commission for Latin America and the Caribbean. (2014). Statistics and indicators. Retrieved from http://www.cepal.org/comercio/ecdata2

European Union-Latin America and Caribbean Foundation (EU-LAC Foundation). (2014). Retrieved from http://eulacfoundation.org/en/about-us

Gallagher, K. P., Irwin, A., \& Koleski, K. (2012). The new banks in town: Chinese finance in Latin America. Retrieved from http://www.thedialogue.org/PublicationFiles/TheNewBanksinTown-FullTextnewversion.pdf

Jiang, S. (2006). A new look at the Chinese relations with Latin America. Retrieved from http://www.nuso.org/upload/articulos/3351_2.pdf

Lee, B. (2014). Chinese President Xi Jinping brings billions on visit to Latin America. Retrieved from http://www.ibtimes.com/chinese-president-xi-jinping-brings-billions-visit-latin-america-1635626

Nowak, W. (2014). Development effectiveness of foreign assistance. Nierówności Spoleczne a Wzrost Gospodarczy, 38(2), 74-84.

Organisation for Economic Co-operation and Development., \& World Trade Organization. (2013). Aid for trade at a glance 2013: Connecting to value chains. Retrieved from http://dx.doi.org/10.1787/aid_glance-2013-en

Ratliff, W. (2009). In search of a balanced relationship: China, Latin America, and the United States. Asian Politics \& Policy, 1(1), $1-30$.

Roy, J. (2012). European Union-Latin American relations in a Turbolent Era. The Jean Monnet/Robert Schumann Paper Series, $12,1-33$.

World Trade Organization. (2014). List of all RTAs. Retrieved from http://rtais.wto.org/UI/PublicAllRTAList.aspx 